\title{
RELEVANSI KURIKULUM CAD SMK BIDANG KEAHLIAN TEKNIK PEMESINAN DENGAN KEBUTUHAN DUNIA USAHA DAN INDUSTRI
}

\author{
Realto Bagyo ${ }^{1}$, Yatin Ngadiyono ${ }^{2}$ \\ ${ }^{1,2}$ Program Studi Pendidikan Teknik Mesin Fakultas Teknik Universitas Negeri Yogyakarta \\ Email: realto.bagyo@gmail.com
}

\begin{abstract}
This research aims to determinate the relevance of CAD curriculum in machining expertise of Vocational High School (SMK) to the work world and industry needs in the Special Region of Yogyakarta and quantify the level of relevance. This research also aims to study the competencies required in the industry which are not accomodated in The SMK 2013 Ccurriculum for machining expertise. The methods for this research is descriptive study with a quantitative approach. The results showed that CAD competencies in the 2013 SMK Curriculum are relevant to the competencies needed by the industry. The level of relevance of the curriculum to the industry needs is $81.67 \%$, or categorized as relevant. The CAD competencies in the 2013 Curriculum are all relevant and needed for the industry, but there are some competencies that have not been accomodated, namely $3 D$ sheet metal modelling, 3D patterns, $2 D$ sheet metal drawings, CAD drawing for CNC machining, Post processsing into CAD/CAM software, plate thickness selection, and the use of bending and roll features.
\end{abstract}

Keywords: relevance, cad, 2013 curriculum, industry needs

\begin{abstract}
ABSTRAK
Tujuan penelitian ini ditujukan untuk mengetahui relevansi kurikulum CAD SMK bidang keahlian teknik pemesinan dengan kompetensi yang dibutuhkan oleh Dunia Usaha dan Industri (DUDI) di Daerah Istimewa Yogyakarta, mengetahui seberapa besar tingkat relevansi antara kurikulum CAD SMK dengan kebutuhan DUDI dan mengetahui kompetensi yang dibutuhkan di industri namun belum terdapat dalam kurikulum 2013 teknik pemesinan SMK. Metode penelitian ini adalah penelitian deskriptif dengan pendekatan kuantitatif. Hasil penelitian menunjukkan kompetensi CAD dalam Kurikulum 2013 SMK relevan dengan kompetensi yang dibutuhkan oleh industri. Besar tingkat relevansi kurikulum CAD SMK dengan kebutuhan industri sebesar 81,67\% atau termasuk dalam kategori relevan. Seluruh kompetensi CAD dalam Kurikulum 2013 SMK dibutuhkan oleh industri, namun terdapat beberapa kompetensi yang perlu ditambahkan yaitu Membuat gambar 3D sheet metal, membuat pattern 3D, Membuat gambar 2D sheet metal, memahami proses gambar untuk CNC, dapat mengimport file ke dalam program MasterCAM, Menetapkan ketebalan plat, dan Penggunaan fungsi bending dan roll.
\end{abstract}

Kata kunci: relevansi kurikulum CAD, kebutuhan industri

\section{PENDAHULUAN}

Perkembangan ilmu pengetahuan teknologi dan informasi yang sangat pesat, membutuhkan pendidikan yang efektif dan efisien. Perlunya upaya menumbuhkan dan mengembangkan potensi-potensi yang dimiliki oleh peserta didik untuk menjadi SDM yang berkualitas. Penyelarasan kurikulum sekolah menengah kejuruan agar sesuai dengan kebutuhan dunia usaha dan dunia industri penting untuk lulusan SMK, melalui Instruksi Presiden (Inpres) Nomor 9 Tahun 2016 tentang revitalisasi SMK untuk meningkatkan kualitas SDM.

Inpres tersebut menugaskan Kementerian Pendidikan dan Kebudayaan (Kemendikbud) untuk membuat peta jalan pengembangan 
SMK, menyempurnakan, dan menyelaraskan kurikulum SMK dengan kompetensi sesuai pengguna lulusan (link and match). Berdasarkan UU Sisdiknas Pasal 15, dinyatakan bahwa pendidikan kejuruan merupakan pendidikan menengah yang mempersiapkan peserta didik terutama untuk bekerja dalam bidang tertentu. Bahkan Peraturan Pemerintah Nomor 29 Tahun 1990 Pasal 3 Ayat (2) menegaskan bahwa pendidikan menengah kejuruan mengutamakan penyiapan peserta didik untuk memasuki lapangan kerja serta mengembangkan sikap profesional.

Kualitas SDM lulusan sekolah menengah (umum maupun kejuruan) secara umum masih belum memenuhi atau tidak sesuai dengan kebutuhan industri, terutama untuk mengisi posisi pekerja tingkat menengah. Suryadi (2010: 5) menyatakan bahwa pendidikan kejuruan telah menimbulkan permasalahan struktural yang menjadikannya kurang relevan dengan lapangan kerja. Menurut Thomas Sukardi (2007: 158) memaparkan makin besar persentase lulusan siswa yang mendapatkan pekerjaan akan makin baik daya serap lulusan suatu sekolah di industri. Perkembangan program studi bersifat konstan karena perangkat pendidikan dibentuk secara resmi dan formal, yang dapat membatasi ruang kreativitas para pengelola program dan terkesan menghindari perubahan. Sebaliknya dunia usaha terus berubah, bahkan teknologi barupun lebih dahulu masuk ke dunia usaha karena mengikuti tuntutan pasar.

Menurut Nugroho Wibowo (2016: 49) terdapat langkah yang sesuai dapat dilakukan sekolah untuk memperkecil kesenjangan antara sekolah menengah kejuruan dengan industri bidang kompetensi lulusan. SMK dapat menyiapkan tenaga kerja yang berkompeten baik dari segi hard skills maupun soft skills sesuai harapan industri. SMK juga dapat melaksanakan program-program kegiatan seperti teaching factory, pengelolaan prakerin, pengelolaan kunjungan industri, penyelenggaraan kelas industri, dan program on job training. Penyuluhan serta pembinaan dari stake holder terkait dengan tenaga kerja juga diperlukan untuk memperkecil kesenjangan antara SMK dengan industri.

Proses merancang atau mendesain dalam dunia industri pemesinan menentukan sesuainya produk dengan kebutuhan manusia. Pada pekerjaan merancang atau mendesain di kebanyakan industri saat ini telah menggunakan CAD (Computer Aided Design) atau CAM (Computer Aided Manufacturing). CAD/CAM mempermudah kegiatan menggambar desain produk di industri, sehingga keberadaan komputer yang dilengkapi software aplikasi CAD/CAM semakin membuat komunikasi dengan bahasa gambar menjadi lebih efisien. Waktu menggambar lebih singkat, dan penyimpanan arsip-arsip gambar lebih ringkas. SMK khususnya pada program keahlian teknik pemesinan memiliki kompetensi menggambar dengan CAD/CAM. Pendidikan dikatakan relevan apabila hasil yang diperoleh akan berguna bagi kehidupan seseorang (Abdullah Idi, 2014: 143). Kompetensi CAD/CAM bertujuan untuk membantu industri mendapatkan perkerja (lulusan SMK) terampil dalam mendesain. Kompetensi CAD yang diberikan di SMK merupakan kompetensi dasar yang masih dapat dikembangkan lagi oleh siswa setelah bekerja di industri.

Kemajuan teknologi berdampak pada proses menggambar menjadi lebih mudah juga berdampak pada berkurangnya tenaga kerja. Kecanggihan teknologi ciptaan manusia telah mampu mengganti berbagai fungsi yang semula harus dikerjakan secara manual. Automation dalam bahasa Indonesia disebut sebagai otomasi merupakan suatu sistem yang memungkinkan pekerjaan dapat selesai dengan lebih mudah serta efektif dan efisien. Suatu sistem otomasi terdiri atas 3 komponen utama yaitu alat atau mesin, sistem kontrol, serta teknologi informasi. Sistem otomasi dapat menciptakan proses produksi yang efisien dan hemat tenaga kerja dalam skala produksi besar. Melalui otomasi robot, tenaga kerja manusia dapat digantikan dengan operasional mesin. 
Meningkatnya perkembangan teknologi dapat mengubah pasar pekerja. Walaupun teknologi mengancam akan menggantikan beberapa pekerjaan manual yang dilakukan manusia, lapangan pekerjaan baru juga dapat terbuka dengan tingginya permintaan untuk sektor teknologi. Penguasaan teknologi menjadi kompetensi yang wajib dikuasai oleh peserta didik sekolah menengah kejuruan dalam menghadapi persaingan dunia kerja. Menurut Benny A Pribadi (2009: 12) kompetensi mencerminkan pengetahuan, keterampilan, dan sikap yang dapat diperlihatkan oleh seseorang setelah menempuh proses pembelajaran.

Tujuan penelitian ini adalah untuk mengetahui relevansi kurikulum CAD SMK bidang keahlian teknik pemesinan yang dibutuhkan oleh DUDI di Daerah Istimewa Yogyakarta. Selain itu untuk mengetahui seberapa besar tingkat relevansi antara kurikulum CAD SMK bidang keahlian teknik pemesinan dengan kebutuhan DUDI. Serta mengetahui kompetensi yang dibutuhkan industri namun belum terdapat dalam kurikulum 2013 teknik pemesinan SMK. Dengan pertimbangan di atas, maka relevansi antara kurikulum CAD SMK bidang keahlian teknik pemesinan dengan kebutuhan dunia usaha dan dunia industri (DUDI) diperlukan.

\section{METODE}

Penelitian ini menggunakan jenis penelitian deskriptif dengan pendekatan kuantitatif. Penelitian deskriptif merupakan penelitian yang dilakukan untuk mengetahui nilai variabel mandiri, baik satu variabel atau lebih tanpa membuat perbandingan, atau menghubungkan dangan variabel lain (Sugiyono, 2012: 13). Penelitian deskriptif kuantitatif di sini dimaksudkan untuk mendapatkan gambaran dan keterangan mengenai relevansi kurikulum CAD SMK dengan kebutuhan dunia usaha dan industri yang diperoleh dari sampel populasi penelitian kemudian dianalisis dengan metode statistik.
Penelitian dilaksanakan pada tanggal 9 September 2019 s/d tanggal 9 Oktober 2019. Tempat penelitian bertempat di industri manufaktur logam yang berada di provinsi Daerah Istimewa Yogyakarta. Tiga industri dijadikan tempat penelitian yaitu UPT. Logam Yogyakarta berlokasi di Kranon Timur Nitikan Umbulharjo Yogyakarta, PT. Mega Andalan Kalasan berlokasi di Jalan Tanjung Tirto 34. Tirtomartani, Yogyakarta, dan PT. Hari Mukti Teknik berlokasi di Jalan Wonosari KM. 8,5 RT.02, Sitimulyo, Piyungan, Bantul, Yogyakarta.

Populasi pada penelitian ini adalah industri manufaktur skala menengah ke atas (yang jumlah tenaga kerjanya antara 20-100 orang atau lebih) di wilayah DIY yang banyak menggunakan teknik gambar dengan CAD dalam proses produksinya. Penentuan sampel dalam penelitian ini menggunakan teknik Purposive sampling atau sampel bertujuan. Penentuan sampel atau terpilihnya industri di atas dengan alasan keterbatasan waktu, perizinan dari industri untuk melakukan penelitian, juga pilihan industri diatas juga telah memenuhi kriteria seperti industri mempunyai jumlah tenaga kerja lebih dari 20 orang dan menggunakan teknik gambar menggunakan program CAD/CAM.

Prosedur penelitian yang dilakukan adalah sebagai pendahuluan untuk menjaga kemungkinan bisa atau tidaknya kegiatan penelitian dilanjutkan. Pendahuluan dimaksudkan juga untuk mencari informasi yang diperlukan oleh peneliti agar masalahnya lebih jelas kedudukannya (Suharsimi Arikunto, 2013: 6). Pendahuluan yang dimaksud adalah observasi dan perizinan untuk melaksanakan penelitian. Responden untuk pengisian angket dalam penelitian ini adalah perwakilan dari industri yaitu Pimpinan, Kepala Bagian, Desainer atau Drafter, dan Operator karena dianggap memiliki pengetahuan tentang kompetensi keahlian CAD/CAM. Data penelitian dalam penelitian ini diperoleh dari observasi, angket, wawancara, dan dokumentasi. 
Penelitian ini menggunakan angket dan kuisioner tertutup berupa Check list dan dalam bentuk skala Likert. Penyusunan instrumen dalam penelitian ini dilakukan dengan berpedoman pada mata pelajaran gambar mesin dengan CAD pada kurikulum 2013. Teknik pengumpulan data penelitian menggunakan wawancara tidak terstruktur dan menggunakan angket atau kuesioner. Angket atau kuesioner dalam penelitian ini berisi sejumlah pertanyaan atau pernyataan berdasarkan standar kompetensi dan kompetensi dasar dalam silabus kurikulum 2013 yang diajarkan pada siswa SMK keahlian teknik pemesinan. Data dari angket tersebut nantinya akan didapatkan kompetensi dasar pada mata pelajaran CAD/CAM yang relevan, cukup relevan, kurang relevan, dan tidak relevan terhadap kebutuhan kompetensi di industri. Angket atau kuesioner tersebut juga diharapkan dapat memberikan informasi mengenai kompetensi yang dibutuhkan di industri manufaktur di DIY tetapi tidak diajarkan di SMK.

Data penelitian dianalisis secara deskriptif kuantitatif dengan persentase. Data masing-masing responden dikumpulkan, ditabulasikan, kemudian disusun dan dianalisis untuk memperoleh jawaban permasalahan yang dirumuskan. Data setelah ditabulasikan kemudian dianalisis secara deskriptif dengan cara menjumlahkan banyaknya nilai jawaban dari setiap kategori untuk masing-masing responden pada setiap standar kompetensi. Selanjutnya mencari persentase dari setiap kelompok standar kompetensi yang dibutuhkan oleh industri. Kemudian persentase setiap kompetensi dasar yang dibutuhkan industri dijumlahkan. Dari hasil penjumlahan kemudian dicari rata-ratanya.

Dalam analisis relevansi kurikulum CAD SMK dengan kebutuhan dunia usaha dan industri, maka persentase setiap skor butir yang didapat dikonversikan ke dalam beberapa kriteria, yaitu: Relevan, Cukup Relevan, Kurang Relevan, dan Tidak Relevan. Adapun pedoman yang digunakan untuk menentukan kriteria tingkat relevansi CAD sebagaimana dikemukakan oleh Suharsimi Arikunto (1993: 210), sesudah sampai persentase lalu ditafsirkan dengan kalimat yang bersifat kualitatif. Pada penelitian ini pengkategorian dinyatakan dalam Relevan (76-100\%), Cukup Relevan (56-75\%), Kurang Relevan (40-55\%), Tidak Relevan (< 40\%). Maka akan diperoleh jawaban atas rumusan masalah pada penelitian ini.

\section{HASIL DAN PEMBAHASAN}

Berdasarkan hasil penelitian kurikulum 2013 bidang CAD di SMK bidang keahlian teknik pemesinan relevan dengan kompetensi yang dibutuhkan oleh dunia industri. Besar tingkat relevansi sebesar $81,67 \%$ termasuk dalam kategori relevan atau sangat dibutuhkan. Hasil tersebut diperoleh dari perhitungan rerata persentase skor setiap Kompetensi Dasar (KD). Persentase skor setiap KD diperoleh dari pengisian angket kuesioner oleh responden yaitu orang yang berkerja dalam bidang CAD di industri. Setiap butir pernyataan dinilai antara 1 sampai dengan 4. Skor yang didapatkan dibagi dengan skor maksimal kemudian di kalikan dengan 100 untuk memperoleh hasil dalam bentuk persentase. Persentase Setiap KD di rata-rata untuk menghasilkan rerata keseluruhan KD. Mata pelajaran CAD di SMK terdiri dari 50 Kompetensi dasar (KD).

Berdasarkan hasil perhitungan dari rerata skor kompetensi CAD dalam kurikulum 2013 SMK, secara keseluruhan termasuk dalam kategori relevan. Besar tingkat relevansi kurikulum CAD dengan industri yaitu sebesar 81,67\%. Setiap kompetensi dasar pada kurikulum CAD terhadap kebutuhan industri maka terdapat 46 kompetensi dasar yang termasuk dalam kategori relevan, terdapat 4 kompetensi dasar yang termasuk dalam kategori cukup relevan, dan tidak terdapat kompetensi dasar yang termasuk dalam kategori kurang relevan dan kategori tidak relevan dari total 50 kompetensi dasar yang terdapat pada kurikulum 2013 mata pelajaran CAD. 
Mata pelajaran CAD di SMK terdapat 46 kompetensi dasar dari 50 kompetensi dasar yang diajarkan di sekolah menengah kejuruan termasuk dalam kategori relevan atau sangat dibutuhkan yaitu sebesar 92,00\%. Terdapat 4 kompetensi dasar dari 50 kompetensi dasar yang diajarkan pada mata pelajaran CAD di sekolah menengah kejuruan termasuk dalam kategori cukup relevan atau dibutuhkan oleh industri manufaktur logam di Daerah Istimewa Yogyakarta. Berikut ini merupakan kompetensi dasar CAD dalam silabus kurikulum 2013 yang diajarkan di SMK yang masuk dalam kategori cukup relevan.

Pertama yaitu kompetensi dasar menunjukkan penggambaran bukaan dengan CAD 2D terdapat 9 responden atau 30,00\% yang menyatakan kurang dibutuhkan. Hal ini menunjukkan bahwa kompetensi menunjukkan penggambaran bukaan dengan CAD 2D masih layak untuk diselenggarakan dengan beberapa evaluasi. Kedua, kompetensi dasar melakukan pembuatan etiket pada gambar CAD 2D terdapat 11 responden atau $36,66 \%$ yang menyatakan kurang dibutuhkan. Hal ini menunjukkan bahwa kompetensi melakukan pembuatan etiket pada gambar CAD 2D masih layak untuk diselenggarakan dengan beberapa evaluasi.

Ketiga, kompetensi dasar menganalisis luas area gambar terdapat 9 responden atau $30,00 \%$ yang menyatakan kurang dibutuhkan. Hal ini menunjukkan bahwa kompetensi menganalisis luas area gambar masih layak untuk diselenggarakan dengan beberapa evaluasi. Terakhir yaitu kompetensi dasar menguasai perhitungan luas area gambar terdapat 7 responden atau $23,34 \%$ yang menyatakan kurang dibutuhkan. Hal ini menunjukkan bahwa kompetensi menguasai perhitungan luas area gambar masih layak untuk diselenggarakan dengan beberapa evaluasi.

Berdasarkan hasil dari seluruh pendapat responden dalam pengambilan data penelitian, seluruh kompetensi dalam silabus kurikulum CAD yang diajarkan di sekolah menengah kejuruan tersebut telah mencakup semua kebutuham industri bidang manufaktur logam di Daerah Istimewa Yogyakarta. Menurut hasil observasi, software aplikasi menggambar (CAD) yang digunakan untuk mendesain produk pada ketiga industri yang paling sering digunakan SolidWorks dan MasterCam. Industri juga menyediakan program aplikasi komputer Autodesk Inventor, Autodesk AutoCAD, MasterCAM 9. Menguasai program tersebut diperlukan menguasai berbagai kompetensi CAD yang diajarkan selama di sekolah.

Kompetensi CAD yang dibutuhkan di industri namun tidak terdapat dalam silabus kurikulum 2013 teknik pemesinan SMK dilihat dari saran atau pendapat responden yang ahli dalam bidang desain di industri. Beberapa kompetensi tersebut yaitu dalam menggunakan program MasterCAM terdapat saran kompetensi seperti membuat gambar 3D sheet metal, membuat pattern 3D, membuat gambar 2D sheet metal, memahami proses gambar untuk CNC, dan dapat mengimport file kedalam program MasterCAM. Menggunakan program SolidWorks terdapat saran kompetensi seperti menetapkan ketebalan plat dan penggunaan fungsi bending dan roll,

Penelitian ini pada dasarnya telah dilaksanakan dengan sebaik-baiknya mulai dari tahap perencanaan hingga tahap penyelesaian laporan. Namun, penelitian ini tidak dapat lepas dari kelemahan-kelemahan atau keterbatasan antara lain tidak semua industri yang akan diambil sebagai responden penelitian mau memberikan izin atau mengisi instrumen. Instrumen yang digunakan untuk mengukur hasil penelitian masih memungkinkan kesalahan tafsir oleh responden.

\section{SIMPULAN}

Kurikulum CAD SMK bidang keahlian teknik pemesinan relevan dengan kompetensi yang dibutuhkan di industri. Besar tingkat relevansi dapat dilihat dari persentase rerata 
relevansi kompetensi sebesar 81,67\% relevan dengan kompetensi yang dibutuhkan oleh dunia industri. Secara keseluruhan sebagian besar kompetensi CAD pada bidang keahlian teknik pemesinan yang diajarkan di SMK dibutuhkan oleh dunia kerja yaitu sebanyak 46 kompetensi yang diajarkan atau 92,00\% termasuk kategori relevan. Akan tetapi masih terdapat 4 kompetensi yang termasuk kategori cukup relevan yang berarti terdapat beberapa responden atau posisi yang kurang membutuhkan kompetensi yang diajarkan di sekolah menengah kejuruan dengan rincian menunjukkan penggambaran bukaan dengan CAD 2D terdapat 9 responden atau 30,00\% yang menyatakan kurang dibutuhkan. Melakukan pembuatan etiket pada gambar CAD 2D terdapat 11 responden atau 36,66\% yang menyatakan kurang dibutuhkan. Menganalisis luas area gambar terdapat 9 responden atau $30,00 \%$ yang menyatakan kurang dibutuhkan. Menguasai perhitungan luas area gambar terdapat 7 responden atau 23,34\% yang menyatakan kurang dibutuhkan.

Semua kompetensi dalam silabus kurikulum CAD yang diajarkan di sekolah menengah kejuruan telah mencakup semua kebutuham industri bidang manufaktur logam di Daerah Istimewa Yogyakarta dan kompetensi industri namun belum terdapat dalam Kurikulum yaitu dalam menggunakan program MasterCAM membuat gambar 3D sheet metal, membuat pattern 3D, membuat gambar 2D sheet metal memahami proses gambar untuk CNC dan dapat mengimport file kedalam program MasterCAM. Dan dalam menggunakan program SolidWorks menetapkan ketebalan plat dan penggunaan fungsi bending dan roll.

\section{DAFTAR RUJUKAN}

Abdullah Idi. (2014). Pengembangan Kurikulum Teori dan Praktik. Jakarta: Rajawali Pers.
Benny A Pribadi. (2009). Model Desain Sistem Pembelajaran. Jakarta: PT. Dian Rakyat.

Depdiknas. (2003). Undang-Undang RI Nomor 20, Tahun 2003, tentang Sistem Pendidikan Nasional.

Nugroho Wibowo. (2016). Upaya Memperkecil Kesenjangan Kompetensi Lulusan Sekolah Menengah Kejuruan dengan Tuntutan Dunia Industri. Jurnal Pendidikan Teknologi dan Kejuruan. Volume 23. Nomor 1, 45-50.

Pemerintah Indonesia. (1990). Peraturan Pemerintah Nomor 29 Tahun 1990 Pasal 3 Ayat (2) tentang Tujuan SMK.

Sekretaris Kabinet Republik Indonesia. (2016). Instruksi Presiden Nomor 9 Tahun 2016 tentang Revitalisasi Sekolah Menengah Kejuruan Dalam Rangka Peningkatan Kualitas dan Daya Saing Sumber Daya Manusia Indonesia.

Sugiyono. (2012). Metode Penelitian Kuantitatif Kualitatif dan $R \& D$. Bandung: Alfabeta.

Suharsimi Arikunto. (2006). Prosedur Penelitian Suatu Pendekatan Praktik. Jakarta: Rineka Cipta.

Suryadi. (2010). Permasalahan dan Alternatif Kebijakan Peningkatan Relevansi Pendidikan (Studi Relevansi Pendidikan Kerjasama UPI dengan Balitbang Kemendiknas). Diakses dari http://file.upi.edu/Direktori/PROCEEDING /Seminar_Internas.NFE.

Thomas Sukardi \& Putut Hargiyarto. (2007). Peran Bursa Kerja Khusus sebagai Upaya Penempatan Lulusan SMK dalam Rangka Terwujudnya Link and Match antara Sekolah dengan Dunia Industri. Jurnal Pendidikan Teknologi dan Kejuruan. Volume 16. Nomor 2, 141-163. 